\title{
Stakeholder Engagement and Financial Performance of Firms Listed on the Johannesburg Stock Exchange (JSE)
}

\author{
Obey Dzomonda*
}

\author{
Department of Business Management, Turfloop Campus, University of Limpopo, Limpopo Province, \\ South Africa
}

\begin{abstract}
Attaining sustainable development will remain an elusive agenda if there is no effective stakeholder engagement. All stakeholders need to come on board to share and collaborate on environmental sustainability initiatives. This study investigated the relationship between stakeholder engagement and financial performance. The study area of this study was all FTSE/JSE listed firms. The researcher opted for a quantitative research approach and used a case study research design. The longitudinal design was adopted where the researcher collected panel data from 2011-2018. The sample of this study was 32 firms listed on the FTSE/JSE Responsible Investment Index. This resulted in 256 observations for the period under consideration. This study utilised secondary data, which is annual financial statements of firms listed on the JSE. Stakeholder engagement was the independent variable while the financial performance as measured by the Tobin's $Q$ was the dependent variable. Quantitative content analysis was used to collect data related to stakeholder engagement. Data was analysed using Panel regression analysis model. The Fixed and Random effects models were used to analyse data. The Hausman test was used to evaluate the appropriate model. The findings showed a positive but insignificant relationship between stakeholder engagement and financial performance as measured by Tobin's Q. This suggested that stakeholder engagement does not predict market valuation of the firm. It was deduced that probably the concerned firms are sending weak signals to key stakeholders regarding their genuine commitment towards environmental sustainability initiatives. Recommendations were made for firms to send strong signals to investors which clearly show that they are genuinely committed towards environmental sustainability initiatives.
\end{abstract}

Keywords: Johannesburg Stock Exchange, Listed firms, Stakeholder engagement, South Africa, Sustainable development.

\section{INTRODUCTION}

Stakeholder engagement has started to gain momentum recently and it is regarded as an effective driver of sustainable development initiatives (Caniëls, Cleophas \& Semeijn, 2016). Attaining sustainable development will remain an elusive agenda if there is no effective stakeholder engagement (Fadly, 2018). All stakeholders need to come on board to share and collaborate on environmental sustainability initiatives. Both internal and external stakeholders of a firm are crucial in supporting the environmental sustainability strategy. It follows that some stakeholders such as suppliers are coming up with innovative environmental solutions and they are willing to share across their supply chain, which can be advantageous to the firm (O'Riordan \& Fairbrass, 2014). Moreover, the role of the community in approving or disapproving environmental sustainability projects cannot be underestimated (Nugraha, Rarasati \& Adiwijaya, 2019). Hence, it is advisable for firms to actively engage its stakeholders to convert possible challenges into drivers for the environmental sustainability agenda. It is effective stakeholder engagement which increases the probability of stakeholder buy-in for a firm's

*Address correspondence to this author at the Department of Business Management, Turfloop Campus, University of Limpopo, Limpopo Province, South Africa; Tel: +27818355324; E-mail: obeydzoms@gmail.com environmental sustainability initiatives (Caniëls et al., 2016; Wang \& Wood, 2016). This is because some of the resources and support structures required by firms to pursue environmental sustainability initiatives are locked in stakeholder networks (Kwamega, Li \& Abrokwah, 2018; Nugraha et al., 2019). The Resource Based View (RBV) theory submits that having access to key resources gives a firm competitive advantage over others (Barney, 2012). Unlocking resources tied in different stakeholders enhances the competitiveness of the firm in the face of its competitors. The competitive advantage is sustained by creating factor conditions which are inimitable by competitors in that industry. These include eco-reputation (Hsu et al., 2016) and stakeholder buy-in which are gained by the firm from active collaborations with supply chain partners (Choi \& Hwang, 2015). For instance, a firm requires new technology from suppliers while at the same time it is employees who will ensure that the new technology is accepted. Hence, when stakeholders are continuously engaged and integrated into environmental related issues and projects which the firm plans to execute, they are likely to support the firm. Stakeholder engagement does not only differentiate a firm from its competitors, but also makes the firm to be efficient and effective in attaining its environmental sustainability goals (Kwamega et al., 2018). This unlocks value and sustainable synergies which translates into superior financial performance. 
It has been noted that several firms are laggards in terms of stakeholder engagement on sustainability initiatives. There is also a scarcity of studies which have investigated the effect of stakeholder engagement on financial performance especially regarding listed firms in South Africa. Thus, this study aims to test the relationship between stakeholder engagement on financial performance of JSE listed firms in South Africa. This study brings to light new empirical evidence which can add value to the body of knowledge and theory since stakeholder engagement has never been tested against the Tobin's $Q$ which is used to measure a firm's future value emanating from different investments. Practically, the findings of this study can assist managers in listed companies to be proactive in terms of stakeholder engagement in sustainability initiatives to harness the benefits associated with this strategy. Essentially, the academia may also use the findings of this study in curving areas for future research. This study is organised as follows;

\section{LITERATURE REVIEW}

\section{Stakeholder Theory}

This study adopts the stakeholder theory propounded by Freeman (1984). The stakeholder theory postulates that the firm does not operate as an island, but its success depends on multiple stakeholders who have different interest on the firm's operations. This means that the firm has to identify these stakeholders and ensure that it fulfils their different needs. On that note, differentiation is made on internal and external stakeholders. Understanding such is crucial for a firm as it enables it to craft different strategies to reach out to these different stakeholders to enable the firm to attain its goals. In the era of sustainability, different stakeholders have unique roles to play to ensure that the firm attains its sustainability goals. Performing poorly on stakeholder relations can hinder firms from attaining desired milestones in sustainable development (Rokhmawati, Gunardi \& Rossi, 2017). Dodson, Azevedo, Mohiuddin, Defavari and Abrahão (2015) assert that organisations should do stakeholder analysis in order to identify key stakeholders and their interests in the organisation. Stakeholder analysis assists a firm to clearly identify and manage different needs of all key stakeholders to avoid future conflicts and lawsuits. Dodson et al. (2015) argue that stakeholder analysis is important in order to accommodate special cases such as the natural environment, which is in most cases, neglected because it does not reflect in company financial statements.

\section{STAKEHOLDER ENGAGEMENT}

Stakeholder engagement is defined as proactive actions taken by firms to collaborate with their key stakeholders on different environmental sustainability initiatives (Yildiz \& Sezen, 2019). Such initiatives allow a firm to attain its long-term vision while at the same time satisfying its key stakeholders (Vanalle, Ganga, Godinho Filho \& Lucato, 2017). In this study, Stakeholder engagement broadly describes initiatives such as green supply chain management (GSCM), stakeholder communication, internal stakeholder collaboration and collaborations with the community on environmental initiatives. These are separately discussed below.

\section{Collaborating with Green Supply Chain Partners}

Stakeholder engagement can be exhibited in a firm's collaborations with its supply chain partners such as green suppliers and green customers. Most studies have used green supply chain management (GSCM) to describe stakeholder engagement (Wang \& Wood, 2016). GSCM is increasingly becoming prominent as pressure towards environmental protection is burgeoning. GSCM is a concept used to infuse green thinking among different stakeholders of the firm in its supply chain (Yildiz \& Sezen, 2019). GSCM practices involve actions taken by the firm to influence suppliers and customers as end users of products to participate in environmental sustainability initiatives. GSCM initiatives include agreements on green product designs, type of materials to be used and collaborations between the business and other supply chain members. Such collaborations enable the firm to enjoy first mover advantages which result in superior financial performance. Additionally, a firm can enhance its overall environmental performance by collaborating with its supply chain partners. Green supply chain partners such as customers and suppliers have unique characteristics of importance to the firm which it can harness to enhance its environmental sustainability initiatives. More importantly, stakeholder engagement can assist a firm in coordinating reverse logistics where they actively collaborate with and encourage customers to recycle the firm's products. Collaborating with suppliers in environmental sustainability initiatives enables a firm to eliminate possible waste at source (upstream), while collaborations with customers assist a firm in ensuring that waste is minimised and unrecyclable materials are properly disposed downstream (Golicic \& Smith, 2013; Dangelico \& Pontrandolfo, 2015; Hsu et al., 2016; Laari et al., 2016; Miroshnychenko et al., 2017). 


\section{Internal Stakeholder Collaborations}

Internal stakeholders such as employees are valuable in the success of environmental sustainability initiatives adopted by a firm. Firms planning to yield positive financial performance from environmental sustainability initiatives should collaborate with their employees from the onset. Through training and development, employees can be green ambassadors of the firm, which enhances brand value and loyalty from the perspective of its customers. This consequently drives sales up as employees are capable of clearly communicating the benefits of green initiatives to the customers. Other researchers further submit that employees possess certain skills which enable the smooth running of the internal and external environmental sustainability initiatives of the firm. However, employees have been neglected in most environmental sustainability issues resulting in resistance to change. Failure to collaborate with internal stakeholders such as employees may create barriers towards the attainment of environmental sustainability (Alfalla-Luque, Marin-Garcia \& MedinaLopez, 2015; Muposhi \& Dhurup, 2016; Kwamega et al., 2018).

\section{Stakeholder Communication}

Effective communication is key in stakeholder engagement. Excellence in stakeholder communication assists a firm in clarifying its specific goals which facilitates buy-in from other supply chain members and can also positively impact on firm financial performance (Boakye, 2018). All stakeholders do not prefer to be left in the dark regarding the operations of the firm (Lannelongue, Gonzalez-Benito \& Gonzalez-Benito, 2015). Firms which continuously engage their stakeholders through newsletters, memos and through their websites are likely to gain trust and loyalty from stakeholders (Boakye, 2018). This can attract investors in the company and suppliers which gives the firm an unmatched competitive advantage. Constant stakeholder engagement makes investors to perceive the firm as transparent (Cheng, loannou \& Serafeim, 2015). In the case of listed firms, transparency is one of the crucial factors which assists investors in deciding whether or not to invest in that company. Based on that, Cheng et al. (2014) reported that stakeholder engagement has a positive effect on financial performance. Additionally, Lannelongue et al. (2015) remark that when a firm invests in stakeholder communication, this enhances their environmental sustainability initiatives through stakeholder feedback, support and buy-in. This translates into superior financial performance and sustainable competitive advantage (Lannelongue et al., 2015). This line of thought augurs well with the Signalling theory which explains that the management should share relevant information with its stakeholders to eliminate information asymmetry. When such is achieved, the firm is likely to enjoy momentous benefits in terms of financial performance which spans into the long run (Haninun et al., 2018).

\section{STAKEHOLDER ENGAGEMENT AND FINANCIAL PERFORMANCE}

The ability of a firm to successfully manage its stakeholders manifests in a health financial performance (Ramakrishnan, 2008). Recently, the focus has shifted from sorely depending on attaining excellence on the tangible assets side to more value creation through developing symbiotic relationships (Hack, 2017). Building symbiotic relationships with stakeholders enables the firm to sustain its positive financial performance (Laughland \& Bansal, 2011). Moreover, maintaining health relationships with stakeholders assures the firm of continued support even in times of financial distress (Laughland \& Bansal, 2011). For instance, with many listed companies filing for business rescue due to financial problems in South Africa, the business rescue process becomes easy if the firm has strong relationships with its stakeholders such as banks and suppliers. In the case of such a strong relationship, banks can extend post commencement funding to the firm while suppliers can extend trade credit facilities, hence, allowing it to bounce back. This entails that intentions and actions by a firm to collaborate with its stakeholders such as suppliers and customers enhance the firm's market value (Laari et al., 2016; Parida \& Wang, 2018). It follows that stakeholder engagement positively influences market-based measures of financial performance.

Golicic and Smith (2013) conducted a study over a 20 -year period. The aim was to evaluate the nexus between GSCM and financial performance. The study established a significant positive relationship between the GSCM and financial performance. It was deduced that stakeholder engagement through GSCM enhances the firm's market valuation by investors. Geng, Mansouri and Aktas (2017) investigated the effect of GSCM and performance using Asian firms. The study was meta-analytic and assessed 50 articles on GSCM. The findings revealed that GSCM positively influence 
financial performance. "Intangibles like trusting relationships with suppliers, employee learning and growth, reputation and goodwill are key drivers of corporate competitiveness and profitability" (Ramakrishnan, 2008:4). Internal stakeholders such as employees also play a crucial role in influencing the viability of environmental sustainability initiatives adopted by a firm (Muposhi \& Dhurup, 2016). Firms that wish to yield positive financial performance from environmental sustainability initiatives should collaborate with their employees from the onset. Through training and development, employees can be green ambassadors of the firm, which enhances brand value and loyalty from the perspective of its customers (Muposhi \& Dhurup, 2016). This consequently drives sales up as employees are capable of clearly communicating the benefits of green initiatives to customers. Excellence in stakeholder communication can also positively impact on firm financial performance (Boakye, 2018). All stakeholders do not prefer to be left in the dark regarding the operations of the firm (Lannelongue et al., 2015). Firms which continuously engage their stakeholders through newsletters, memos and through their websites are likely to gain trust and loyalty from stakeholders (Boakye, 2018). This can attract investors in the company and suppliers which gives the firm an unmatched competitive advantage. Constant stakeholder engagement makes investors to perceive the firm as transparent (Cheng et al., 2015). In the case of listed firms, transparency is one of the crucial factors which assist investors in deciding whether to invest in that company or not. Based on that, Cheng et al. (2015) reported that stakeholder engagement is positively related to financial performance. Additionally, Lannelongue et al. (2015) remark that when a firm invests in stakeholder communication, this enhances their environmental sustainability initiatives through stakeholder feedback, support and buy in. This translates into superior financial performance and sustainable competitive advantage (Lannelongue et al., 2015). Stakeholder engagement enhances the longevity and financial performance of a firm (Haninun et al., 2018). Stakeholders possess the resources required by a firm to execute its environmental sustainability initiatives (Laughland \& Bansal, 2011). The Resource Based View (RBV) theory submits that having access to key resources gives a firm a competitive advantage over others. For instance, a firm requires new technology from suppliers while at the same time it is its employees who will ensure that the new technology is accepted. Hence, when stakeholders are continuously engaged on environmental related issues and projects which the firm plans to execute, they are likely to support the firm. This unlocks value and sustainable synergies which translates into superior financial performance. This view is supported by the Signaling theory which explains that management should share relevant information with its stakeholders to eliminate information asymmetry. When such is achieved, the firm is likely to enjoy momentus benefits in terms of financial performance which spans into the long run (Haninun et al., 2018).

Nevertheless, some studies argue that stakeholder engagement can bring unnecessary costs to the firm which can weaken its profitability (Eunice, 2014; Jones, Harrison \& Felps, 2018). The argument is that stakeholder engagement especially for green initiatives require huge investments of money. Hence, given the stiff competition that listed firms encounter, this can negatively affect the firm resulting in losses (Eunice, 2014). In support of the negative relationship between stakeholder engagement and financial performance, other studies argue that investment in stakeholder initiatives can disadvantage them in terms of resource allocation (Zhong, 2013). This is usually the case in most emerging markets where environmental policy and regulations are relatively weak. This means that non-participating firms will remain better off at the expense of their counterparts who take environmental sustainability issues seriously. Stakeholders may also have different needs which may make the firm to lose focus on its main goal. There is also a tendency by management to fund their personal interests in the name of stakeholder engagement. This negatively impacts on the financial performance of a firm (Cennamo, Berrone \& Gomez-Mejia, 2009). Dam and Petkova (2014) investigated the relationship between stakeholder engagement in the form of collaboration on environmental sustainability initiatives between the firm and its suppliers. The study found that stakeholder engagement in this case was negatively related to financial performance as measured by share price. The argument behind such a result was that markets can respond negatively to announcements by a firm that they are engaging in environmental sustainability initiatives. This is because most stakeholders associate such moves with greenwashing (Griese et al., 2017; Khandelwal et al., 2019).

The last strand of literature refutes the claims that stakeholder engagement has an effect on financial performance. A study by Zaccheaus, Oluwagbemiga and Olugbenga (2014) analysed the relationship 
between stakeholder engagement and financial performance. The study used Nigerian listed firms and established an insignificant relationship between stakeholder engagement and financial performance.

The author of this study is of the view that stakeholder engagement can enhance financial performance among listed firms. The argument is that through stakeholder engagement initiatives such as green supply chain collaborations, stakeholders' communication and partnering with the community or the government can go a long way in making environmental sustainability initiatives a success. Moreover, the resources required by firms to pursue environmental sustainability initiatives are locked among key stakeholders such as investors, suppliers and the government. Essentially, firms which effectively engage their key stakeholders on environmental protection initiatives and projects are likely to attract a favourable rating from stakeholders which enhances the future value of the business as measured by the Tobin's Q. Moreover, active stakeholder engagements can help firms to send strong signals about their environmentally responsible behaviour which can earn them green trust from stakeholders which enhances their image. Firms with a positive image can command a premium on their products because of the goodwill the brand has. This stands a low hanging fruit strategy to enhance financial performance. Based on the above evidence, this study proposes to test the following hypothesis:

Ha: There is a significant positive relationship between stakeholder engagement and Tobin's $Q$ of firms listed on the JSE.

\section{RESEARCH METHODOLOGY}

The study area of this study was all FTSE/JSE listed firms. The researcher opted for a quantitative research approach and used a case study research design. This is because the researcher intended to collect data from several listed firms. The longitudinal design was adopted where the researcher collected panel data from 2011-2018. The reason for considering this period was that integrated financial reporting was introduced in 2010 in South Africa. Hence, relevant data was obtainable from 2011 and beyond (Leigh, 2017). All firms listed on the JSE were considered as the population of this study. The choice to consider JSE listed firms was that these are critically scrutinised in terms of sustainability engagement and reporting (JSE, 2019).

\section{Sample Description}

The sample of this study was 30 firms listed on the FTSE/JSE Responsible Investment Index. Nevertheless, 2 companies on the list had dual listings which made the number of firms to be 32 . The dual listing means that 2 companies were listed on the London stock exchange with a secondary listing in South Africa (JSE). This resulted in 256 observations for the period under consideration. The 32 firms considered firms belonged to different industries such as the mining industry, manufacturing, banking, health and pharmaceuticals, retail, telecommunications, energy and the services sector. The FTSE/JSE Responsible Investment Index is an index formed by the partnership between the JSE and the FTSE Russell in June 2015 in a bid to promote sustainable behaviour among listed firms. The firms on the FTSE/JSE Responsible Investment Index have been actively involved in sustainability practices (JSE, 2019). Additionally, they have satisfied the reporting requirements for both the FTSE and the JSE. This assisted the researcher to access all the data required to test the hypotheses of the study. This addressed the issue of missing data which usually causes problems in research (Putz, 2017).

\section{Data Collection}

This study utilised secondary data, which is annual financial statements of firms listed on the JSE. The data provided by these firms is critically audited to enhance transparency (Amacha and Dastane, 2017). Secondary data is widely used in studies linking environmental sustainability to financial performance (Ong, Teh \& Ang, 2014; Amacha and Dastane, 2017; Boakye, 2018). Financial performance data such as Tobin's $Q$, liquidity and firm size was collected from integrated annual financial statements on the firm's websites and the McGregor database. Quantitative content analysis was used to collect data related to stakeholder engagement. The research used a dichotomous scale ranging from 0 and 1 for objectivity (Mans-Kemp, 2014). During data collection, a score of 0 was allocated when the variable was not reported and a score of 1 was allocated when the variable was reported in the financial year following similar studies (Galant \& Cadez, 2017; Boakye, 2018). Data was analysed using Panel regression analysis model. The Fixed and Random effects models were used to analyse data. The Hausman test was used to evaluate the appropriate model to use between the fixed effects 
and the random effect model depending on the data set provided (Pedace, 2013).

\section{Measurement of Variables}

\section{Dependant Variable (Financial Performance)}

The dependent variable of the study was financial performance. This study adopted the market-based measure of financial performance. Specifically, the Tobin's $Q$ was used as a measure of financial performance. "The $Q$ ratio is defined as the market value of a firm divided by the replacement cost of the firm's assets" (Fu et al., 2016:1). It is also used to measure a firm's long run financial performance. As such, the Tobin's $Q$ is highly regarded as a key ratio that informs future investment decisions in existing literature. The value of 1 for Tobin's $Q$ indicates a favourable state of the firm. A higher Tobin's $Q$ signals investors that the firm value will appreciate in future, hence, guaranteeing them of future gains (Sethibe \& Steyn, 2016; Manrique \& Martí-Ballester, 2017). According to the Signaling theory, a firm with a positive Tobin's $Q$ is able to send a positive signal to the market.

\section{Independent Variable/s (Stakeholder engagement)}

The independent variable of the study was stakeholder engagement. Information regarding to this variable was derived from the GRI guidelines (EN category). The GRI indicators have been used widely as guidelines on measures of sustainability (Amacha \& Dastane, 2017). Stakeholder engagement was measured using elements such as green supply chain management (GSCM), stakeholder communication, internal stakeholder collaboration and collaborations with the community on environmental initiatives. These measures were each tracked using content analysis on the companies' websites and sustainability reports.

Dependent Variable; Y: Financial Performance

Dependent variable 1; Y: Tobin's $Q$

\section{Independent Variable; X: Stakeholder Engagement}

Independent variable 1; X1: Stakeholder engagement

\section{Panel Regression Model}

$Y_{i t}=\alpha+X_{1 i t}+X_{2 i t}++X_{3 i t}+\varepsilon$

Where $y=$ financial performance; $x_{1}=$ stakeholder engagement; $x_{2}=$ firm size; $x_{3}=$ Liquidity; $+\varepsilon=$ error term; $\alpha=$ constant

\section{Control Variables}

It is important to determine if other underlying factors have an influence on the dependent variable (Maleka, Nyirenda \& Fakoya, 2017). Hence, these factors should be tested prior to the independent variable to provide an alternate explanation for the findings. Control variables such as firm size and liquidity were used following similar studies (Jayeola, 2015; Horváthová, 2016). This is because the size of the firm and liquidity have an effect on the overall financial performance of a firm (Marashdeh, 2014; AIShahrani \& Tu, 2016). In this study, market capitalisation was used to measure the size of the firm while liquidity was measured by compiling values from the current ratio of firms which were evaluated.

\section{RESULTS}

\section{Descriptive Statistics}

The total number of observations was 256 derived from 32 firms observed for 8 years. Stakeholder engagement had a mean of 3,945313 and a standard deviation of 0,3018529 . The minimum value for stakeholder engagement was 0 and the maximum was 4. In terms of Tobin's $Q$, the mean score was 1,673086 and the standard deviation was 1,341552, while the minimum value was 0.22 and the maximum value was 7.05. The mean for liquidity was 1.425118 and the standard deviation was 0.9830142 . The minimum value for liquidity was 0 and the maximum value was 6.8176 . Considering firm size, the mean score was 9297.23

Table 1: Descriptive Statistics

\begin{tabular}{|c|c|c|c|c|c|}
\hline Variable & Obs & Mean & Std. Dev. & Min & Max \\
\hline \hline Stakeholder engagement & 256 & 3,945313 & 0,3018529 & 4 \\
\hline Tobin's Q & 256 & 1,673086 & 1,341552 & 0,22 & 7,05 \\
\hline Liquidity & 256 & 1,425118 & 0,9830142 & 0 & 6,8176 \\
\hline Firm size & 256 & 9297,23 & 47711,28 & 0 & 428668 \\
\hline
\end{tabular}


Table 2: Correlation Analysis

\begin{tabular}{|c|c|c|c|c|}
\hline Variables & Tobin's $\mathbf{Q}$ & Liquidity & Firm size & Stakeholder engagement \\
\hline \hline Tobin's $Q$ & 1 & & & \\
\hline Liquidity & 0.033 & 1 & 1 & \\
\hline Firm size & 0.0151 & $-0,0058$ & $-0,0051$ & 0,0951 \\
\hline
\end{tabular}

and the standard deviation was 47711.28. The minimum value was 0 and the maximum value was 428668 .

\section{Correlation Analysis}

Table 2 shows correlation analysis results among the key variables of the study. Stakeholder engagement was found to be negatively correlated with Tobin's $Q(-0.136)$ and liquidity $(-0.0051)$ respectively. On the other hand, a possitive correlation (0.0951) was established between stakeholder engagement and firm size.

\section{DIAGNOSTIC TESTS}

It was crucial to test if the data met all the assumptions of the panel regression. This is crucial because it enhances the accuracy of the model. To that effect, the following diagnostic tests were conducted on the data.

\section{Normality}

It is crucial to test for normality in panel data. Data which assumes a normal distribution curve increases the likelihood of getting quality results. In this study, the data passed the normality test and generally all the variables were normally distributed as shown in Figure 1.

\section{Multicollinearity}

Multicollinearity is another element which should be verified when using panel data. "Multicollinearity exists when two or more variables of the predictors in a regression model are positively or negatively correlated" (Boakye, 2018:176). Multicollinearity is tested using variance inflation factors (VIF). As shown by VIF values in Table 3, there was no multicollinearity within the data. This is because all the VIF values on the variables are less than 10.

\section{Autocorrelation}

It is crucial to test for serial autocorrelation in panel data. This is because serial autocorrelation can bias the findings of the study (Masadeh, 2014). In this study the Breausch-Godfrey LM test was used to test for autocorrelation. The $p$ value of 0.8601 shows that the data did not have autocorrelation.

\section{Heteroskedasticity}

The Breusch and Pagan test was used to assess the presence of heteroscedasticity. According to Field

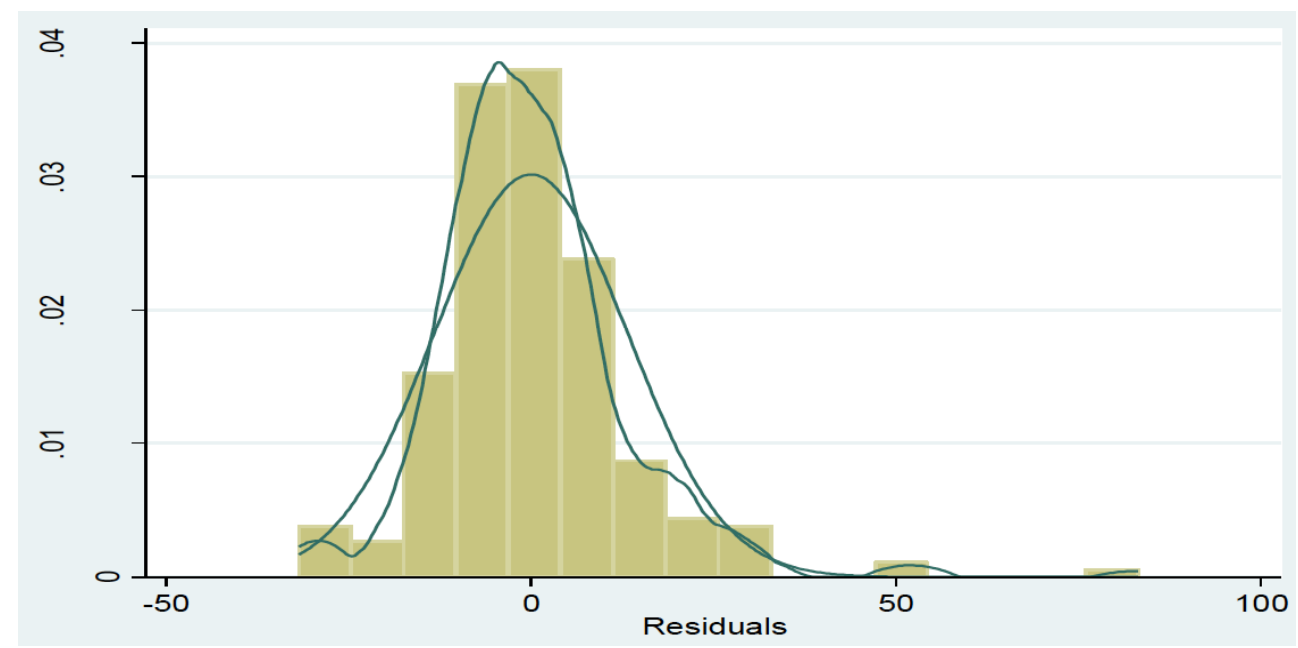

Figure 1: Test for normality. 
Table 3: Test for Multicollinearity

\begin{tabular}{|c|c|c|}
\hline Variable & VIF & $\mathbf{1 / V I F}$ \\
\hline \hline Stakeholder engagement & 1.04 & 0.959053 \\
\hline Firm size & 1.17 & 0.855648 \\
\hline Liquidity & 1.02 & 0.976330 \\
\hline Mean VIF & 1.08 & \\
\hline
\end{tabular}

Table 4: Breausch-Godfrey LM Test for Autocorrelation

\begin{tabular}{|c|c|c|c|}
\hline Lags $(\mathbf{p})$ & Chi2 & df & Prob>chi2 \\
\hline \hline 1 & 0.031 & 1 & 0.8601 \\
\hline
\end{tabular}

HO: no serial correlation.

(2013), the presence of heteroscedasticity in panel data may weaken the analysis. Hence, it is crucial to test it and find ways to eliminate or suppress it. Values less than 0.05 show that there is heteroscedasticity in the panel data. The Breusch and Pagan test produced a $p$ value of 0.39 . This shows that the data was free from heteroscedasticity.

\section{STAKEHOLDER ENGAGEMENT AND FINANCIAL PERFORMANCE}

\section{Fixed Effects Model on Tobin's Q}

Table 5 present the findings on relationship between stakeholder engagement and the financial performance. The findings show a weak and positive relationship between stakeholder engagement and the Tobin's Q (0.1129332, p. 0.659). A p value of 0.659 exceeds the recommended $p$ value of 0.05 which means the relationship is insignificant. The implication of this is that stakeholder engagement has no effect on the market value of a firm as measured by the Tobin's Q.

\section{Random Effects Model on Tobin's Q}

Table 6 presents findings of the Random effects model on Tobin's $Q$. The findings show that there is a positive (0.1378072; p. 0.583) but insignificant

Table 5: Fixed Effects Model on Tobin's Q

\begin{tabular}{|c|c|c|c|c|c|c|}
\hline \multicolumn{3}{|c|}{ Fixed effects (within regression) } & & & \multirow{2}{*}{$\begin{array}{r}\text { Number of obs }= \\
\text { Number of groups }=\end{array}$} & \multirow{2}{*}{$\begin{array}{l}256 \\
8 \\
\end{array}$} \\
\hline Group variable: Year & & & & & & \\
\hline R-sq: within $=$ & 0.2537 & & & & Obs per group:min= & 32 \\
\hline Between $=$ & 0.0032 & & & & $\operatorname{avg}=$ & 32 \\
\hline Overall $=$ & 0.2482 & & & & $\max =$ & 32 \\
\hline \multirow[t]{2}{*}{ Corr $\left(u \_i, X b\right)=$} & 0.0097 & & & & $F(10,238)=$ & 8.09 \\
\hline & & & & & Prob $>\mathrm{F}=$ & 0.0000 \\
\hline Tobin's Q & Coef. & Std. Err. & $\mathbf{t}$ & $P>|t|$ & [95\% Confi. & Interval] \\
\hline Stakeholder engagement & 0.1129332 & 0.255249 & 0.44 & 0.659 & -0.3899026 & 0.6157691 \\
\hline Liquidity & 0.2871958 & 0.0767063 & 3.74 & 0.000 & 0.1360857 & 0.4383059 \\
\hline Firm size & $7.40 \mathrm{e}-06$ & $1.70 \mathrm{e}-06$ & 4.35 & 0.000 & $4.05 e-06$ & 0.0000108 \\
\hline _cons & 3.362703 & 1.19719 & 2.81 & 0.005 & 1.00426 & 5.721145 \\
\hline Sigma_u & 0.19939072 & & & & & \\
\hline Sigma_e & 1.1884207 & & & & & \\
\hline rho & 0.02737873 & & (fractio & varianc & & \\
\hline$F$ test that all $u_{-} i=0$ : & \multicolumn{2}{|c|}{$F(7,238)=0.84$} & & & $F=0.5579$ & \\
\hline
\end{tabular}


Table 6: Random Effects Model on Tobin's Q

\begin{tabular}{|c|c|c|c|c|c|c|}
\hline \multicolumn{3}{|c|}{ Random effects GLS regression } & & & Number of obs $=$ & 256 \\
\hline \multicolumn{2}{|c|}{ Group variable: Year } & & & & Number of groups $=$ & 8 \\
\hline R-sq: within = & 0.2524 & & & & Obs per group: $\min =$ & 32 \\
\hline between $=$ & 0.1702 & & & & $\operatorname{avg}=$ & 32 \\
\hline overall = & 0.2496 & & & & $\max =$ & 32 \\
\hline \multirow[t]{2}{*}{ Corr $\left(u_{-} \_,\right.$X $)=$} & assumed & & & & Wald chi2 $(10)=$ & 81.47 \\
\hline & & & & & Prob $>$ chi $2=$ & 0.0000 \\
\hline Tobin's Q & Coef. & Std. Err. & $\mathbf{z}$ & $P>|z|$ & [95\% Confi. & Interval] \\
\hline Stakeholder engagement & 0.1378072 & 0.2511696 & 0.55 & 0.583 & -0.3544761 & 0.6300905 \\
\hline Liquidity & 0.2901161 & 0.0764409 & 3.80 & 0.000 & 0.1402947 & 0.4399374 \\
\hline Firm size & $6.98 e-06$ & $1.68 e-06$ & 4.15 & 0.000 & $3.68 e-06$ & 0.0000103 \\
\hline _cons & 3.399848 & 1.181001 & 2.88 & 0.004 & 1.085129 & 5.714566 \\
\hline Sigma_u & 0 & & & & & \\
\hline Sigma_e & 1.1884207 & & & & & \\
\hline rho & 0 & (fraction of & ance $d$ & $\left.o u \_i\right)$ & & \\
\hline
\end{tabular}

relationship between stakeholder engagement and Tobin's $Q$. This is because the p. value $(0.583)$ is greater than the recommended significance $p$ value of 0.05. This implies that Stakeholder engagement does not predict financial performance among the JSE listed firms.

\section{Hausman Test}

The Hausman test was used to evaluate the appropriate model to use between the fixed effects and the random effect model (Pedace, 2013). The Hausman test null hypothesis states that the random effects is the preferred model (Snorrason, 2012). It follows that when the Hausman test is significant at ( $p$ $<0.05$ ), then the fixed effect model will be the appropriate model (Hassett \& Paavilainen-Mäntymäki, 2013). Based on the Hausman test in Table 5 (p. 0.8232 ) is above p. 0.05. This means the Random effects is the perfect model for the data, the results from the Random effects model were considered for this study.

\section{DISCUSSION}

A weak, positive and insignificant relationship was found between stakeholder engagement and the Tobin's Q. Although the relationship is insignificant, it can be inferred that stakeholder engagement initiatives such as stakeholder communication and collaborating with stakeholders in environmental sustainability projects may positively influence financial performance.

Table 7: Hausman Test

\begin{tabular}{|c|c|c|c|c|}
\hline & (b) & (B) & (b-B) & Sqrt(diag(V_b-V_B)) \\
\hline & FEM & REM & Difference & S.E. \\
\hline Stakeholder engagement & 0.1129332 & 0.1378072 & -0.024874 & 0.0454522 \\
\hline Liquidity & 0.2871958 & 0.2901161 & -0.0029203 & 0.0063763 \\
\hline Firm size & $7.40 \mathrm{e}-06$ & $6.98 e-06$ & $4.26 \mathrm{e}-07$ & $2.57 e-07$ \\
\hline \multicolumn{5}{|c|}{$\mathrm{b}=$ consistent under $\mathrm{Ho}$ and $\mathrm{Ha}$; obtained from $\mathrm{xtreg}$} \\
\hline \multicolumn{5}{|c|}{$\mathrm{B}=$ inconsistent under $\mathrm{Ha}$, efficient under $\mathrm{Ho}$; obtained from xtreg } \\
\hline \multicolumn{5}{|c|}{ Ho: difference in coefficients not systematic } \\
\hline \multicolumn{5}{|c|}{$\operatorname{chi} 2(9)=(b-B))^{\prime}\left[\left(V \_b-V \_B\right)^{\wedge}(-1)\right](b-B)$} \\
\hline \multicolumn{5}{|c|}{$=5.13$} \\
\hline \multicolumn{5}{|c|}{ Prob $>$ chi $2=0.8232$} \\
\hline
\end{tabular}


Nevertheless, the effect is minimal and does not determine the profitability of the firm. It can be inferred that investors are still pessimistic on the importance of considering stakeholder engagement to determine the future value of a firm. One of the challenges confronting most firms is being driven by the profit maximisation goal that stakeholder engagement is not viewed as something that can help a business to generate profit. According to the Signaling theory, a firm should be able to send positive signals to the market. Such signals have a positive influence on the firm's growth prospects. The signal should be clear enough for the investors to notice. Due to vastness of information, it is becoming relatively easy for investors to pick out a genuine signal from just a marketing gimmick. There is an argument that some firms' sustainability initiatives fail to pay because they fail to send strong signals to investors that their environmental responsibility have improved (Kurniaty et al., 2018; Wijayanto et al., 2019). This might be the case with the firms investigated in this study. Several firms might be conducting stakeholder engagement minimally which might not be strong enough to send strong signals to the market regarding the extent to which the firm commits towards environmental initiatives.

Consequently, investors may perceive such news as green washing by the firm (Riaz et al., 2019). This may lead to a negative valuation of the firm's shares, hence, a negative relationship between energy efficiency and share price. On the other end of the of the spectrum, stakeholders such as customers react negatively to environmental certifications as they still perceive it as one of the marketing gimmicks used by firms to increase sales without necessarily adding value towards environmental protection (Riaz et al., 2019). Among the few studies which reported an insignificant relationship is a study by Zaccheaus et al. (2014). The study analysed the relationship between stakeholder engagement and financial performance using Nigerian listed firms. The study established an insignificant relationship between stakeholder engagement on environmental issues and financial performance as measured by share price.

This study shares different findings altogether with other existing empirical studies. These studies express that stakeholder engagement positively influences financial performance. For example, Geng et al. (2017) investigated the effect of GSCM and performance using Asian firms. The study was meta-analytic and assessed 50 articles on GSCM. The findings revealed that GSCM positively influence financial performance. According to Muposhi \& Dhurup (2016), firms that wish to yield positive financial performance from environmental sustainability initiatives should collaborate with their employees from the onset. Through training and development, employees can be green ambassadors of the firm, which enhances brand value and loyalty from the perspective of its customers (Muposhi \& Dhurup, 2016). This consequently drives sales up as employees are capable of clearly communicating the benefits of green initiatives to customers.

Excellence in stakeholder communication can also positively impact on firm financial performance (Boakye, 2018). All stakeholders do not prefer to be left in the dark regarding the operations of the firm (Lannelongue et al., 2015). Firms which continuously engage their stakeholders through newsletters, memos and through their websites are likely to gain trust and loyalty from stakeholders (Boakye, 2018). This can attract investors in the company and suppliers which gives the firm an unmatched competitive advantage. Constant stakeholder engagement makes investors to perceive the firm as transparent (Cheng et al., 2014). In the case of listed firms, transparency is one of the crucial factors which assist investors in deciding whether to invest in that company or not. Based on that, Cheng et al. (2014) reported that stakeholder engagement is positively related to financial performance. Additionally, Lannelongue et al. (2015) remark that when a firm invests in stakeholder communication, this enhances their environmental sustainability initiatives through stakeholder feedback, support and buy in. This translates into superior financial performance and sustainable competitive advantage (Lannelongue et al., 2015).

Based on the synthesis of the findings of the current study and existing empirical findings, the insignificant relationship established between stakeholder engagement and financial performance can be attributed to contextual factors. For example, it might be that the market in South Africa does not perceive stakeholder engagement initiatives as genuine. Nevertheless, with time, the different stakeholders may start to appreciate the efforts of firms which might change their perception towards stakeholder engagement.

\section{CONCLUSION}

Attaining sustainable development will remain an elusive agenda if there is no effective stakeholder 
engagement. All stakeholders need to come on board to share and collaborate on environmental sustainability initiatives. Hence, both internal and external stakeholders of a firm are crucial in supporting the environmental sustainability strategy. This study investigated the relationship between stakeholder engagement and financial performance. The findings showed a positive but insignificant relationship between stakeholder engagement and financial performance as measured by Tobin's $Q$. This suggested that stakeholder engagement does not predict market valuation of the firm. It was deduced that probably the concerned firms are sending weak signals to key stakeholders regarding their genuine commitment towards environmental sustainability initiatives. The author of this study believes that firms may unlock nonfinancial value for their business by actively engaging in stakeholder management. This is because the future of business longevity will depend more on the relationships that the business has with its key stakeholders. The practical implication of this study is that the findings of this study can assist managers in listed companies to be proactive in terms of stakeholder engagement in sustainability initiatives to harness the benefits associated with this strategy.

\section{RECOMMENDATIONS}

The findings showed that the relationship between stakeholder engagement and financial performance as measured by Tobin's $Q$ was positive but insignificant. Hence, listed firms are recommended to send strong signals to investors which clearly show that they are genuinely committed towards environmental sustainability initiatives. This can be done by partnering with stakeholders such as the community, suppliers and investors in environmental sustainability projects. Taking such a step can send a strong signal to the market which can improve the financial performance as measured by the Tobin's Q. Additionally, managers of listed firms are encouraged to look for effective ways to engage stakeholders on environmental initiatives. On the other end, stakeholders such as investors are encouraged to change their perception towards listed firms' stakeholder engagement activities. As was found during data collection, a significant number of listed firms are seriously investing in sustainability initiatives which is opposed to greenwashing as perceived by some stakeholders.

\section{REFERENCES}

Alfalla-Luque, R., Marin-Garcia, J.A. \& Medina-Lopez, C. (2015). 'An analysis of the direct and mediated effects of employee commitment and supply chain integration on organisational performance. International Journal of Production Economics, 162, 242-257.

https://doi.org/10.1016/j.ijpe.2014.07.004

Amacha, E. \& Dastane, O. (2017). Sustainability Practices as Determinants of Financial Performance: A Case of Malaysian Corporations. The Journal of Asian Finance, Economics and Business, 4(2), 55-68. https://doi.org/10.13106/jafeb.2017.vol4.no2.55

Barney, J.B. (2012). 'Purchasing, supply chain management and sustained competitive advantage: The relevance of resourcebased theory. Journal of Supply Chain Management, 48(2), 3-6. https://doi.org/10.1111/j.1745-493X.2012.03265.x

Boakye, D.J. (2018). The Relationship between Environmental Management Quality and Financial Performance of AIM listed Firms. Doctoral thesis, Bournemouth University.

Caniëls, M. C., Cleophas, E. \& Semeijn, J. (2016). Implementing green supply chain practices: an empirical investigation in the shipbuilding industry. Maritime Policy \& Management, 43(8), 1005-1020.

https://doi.org/10.1080/03088839.2016.1182654

Cennamo, C., Berrone, P. \& Gomez-Mejia, L.R. (2009). Does stakeholder management have a dark side? Journal of Business Ethics, 89(4), 491-507. https://doi.org/10.1007/s10551-008-0012-x

Cheng, B., loannou, I. \& Serafeim, G. (2014). Corporate social responsibility and access to finance. Strategic Management Journal, 35(1), 1-23. https://doi.org/10.1002/smi.2131

Cheng, C.C., Yang, C.L. \& Sheu, C. (2015). The link between ecoinnovation and business performance: A Taiwanese industry context. Journal of Cleaner Production, 64, 81-90. https://doi.org/10.1016/j.jclepro.2013.09.050

Choi, D. \& Hwang, T. (2015). The impact of green supply chain management practices on firm performance: the role of collaborative capability. Operations Management Research, 8(3-4), 69-83. https://doi.org/10.1007/s12063-015-0100-x

Dam, L. \& Petkova, B.N. (2014). The impact of environmental supply chain sustainability programs on shareholder wealth. International Journal of Operations \& Production Management, 34(5), 586-609. https://doi.org/10.1108/IJOPM-10-2012-0482

Dangelico, R.M. \& Pontrandolfo, P. (2015). Being "green and competitive": the impact of environmental actions and collaborations on firm performance. Business Strategy Environment, 24, 413-430. https://doi.org/10.1002/bse.1828

Dodson, M. S., de Azevedo, D. B., Mohiuddin, M., Defavari, G. H. \& Abrahão, A.F. S. (2015). Natural Environment and Future Generations as Stakeholders, the path for Sustainability. Desafio Online, 3(2), 55-74.

Eunice. (2014). Corporate Social Responsibility as a Marketing Strategy for Enhanced Performance in the Nigerian Banking Industry: A Granger Causality Approach. Procedia-Social and Behavioral Sciences,164(31), 141-149. https://doi.org/10.1016/j.sbspro.2014.11.062

Fadly, D. (2018). Greening industry in Vietnam: Environmental standards and resource efficiency in SMEs. [Online]. Available: http://www.greengrowthknowledge.org/sites/ default/files/uploads/Dalia\%20Fadly $\% 20 \% 20$ Greening\%20In dustry\%20in\%20Vietnam_0.pdf. Accessed on 12 June 2019.

Field, A. (2013). Discovering statistics using IBM SPSS statistics. sage.

Freeman, R. E. 1984. Strategic management: A stakeholder approach. Boston:

Fu, L., Singhal, R. \& Parkash, M. (2018). Tobin's q Ratio and Firm Performance. International Research Journal of Applied Finance, VII(4), 1-10. 
Galant, A. \& Cadez, S. (2017). Corporate social responsibility and financial performance relationship: A review of measurement approaches. Economic research-Ekonomska istraživanja, 30(1), 676-693.

https://doi.org/10.1080/1331677X.2017.1313122

Geng, R., Mansouri, S.A. \& Aktas, E. (2017). The relationship between green supply chain management and performance: A meta-analysis of empirical evidences in Asian emerging economies. International Journal of Production Economics, 183, 245-258. https://doi.org/10.1016/j.ijpe.2016.10.008

Golicic, S.L. \& Smith, C.D. (2013). A meta-analysis of environmentally sustainable supply chain management practices and firm performance. Journal of Supply Chain Management, 49, 78-95. https://doi.org/10.1111/jscm.12006

Griese, K. M., Werner, K. \& Hogg, J. (2017). Avoiding Greenwashing in Event Marketing: An Exploration of Concepts, Literature and Methods. Journal of Management and Sustainability, 7(1), 1-15. https://doi.org/10.5539/jms.v7n4p1

Hack, N.B. (2017). Improving Stakeholder Engagement Increases Productivity, Profit and Sustainability. [Online]. Available: https://www.huffpost.com/entry/stakeholderengagement_b_1556070. Accessed on 10 May 2019.

Haninun, H., Lindrianasari, L. \& Denziana, A. (2018). The effect of environmental performance and disclosure on financial performance. International Journal of Trade and Global Markets, 11(1-2), 138-148. https://doi.org/10.1504/IJTGM.2018.092471

Hassett, M.E. \& Paavilainen-Mäntymäki, E. (2013). Handbook of longitudinal research methods in organisations and business studies. Cheltenham: Edward Elgar. https://doi.org/10.4337/9780857936790

Horváthová, E. (2016). The impact of environmental performance on firm performance: Short-term costs and long-term benefits? Ecological Economics, 84, 91-97. https://doi.org/10.1016/j.ecolecon.2012.10.001

Hsu, C.C., Tan, K.C. \& Mohamad Z.S.H. (2016). Strategic orientations, sustainable supply chain initiatives, and reverse logistics: Empirical evidence from an emerging market. International Journal of Operations \& Production Management, 36(1), 86-110. https://doi.org/10.1108/IJOPM-06-2014-0252

Jayeola, O. (2015). The impact of environmental sustainability practice on the financial performance of SMEs: A study of some selected SMEs in Sussex. International Journal of Business Management and Economic Research, 6(4), 214230

Jones, T. M., Harrison, J. S. \& Felps, W. (2018). How applying instrumental stakeholder theory can provide sustainable competitive advantage. Academy of Management Review, 43(3), 371-391.

https://doi.org/10.5465/amr.2016.0111

Johannesburg Stock Exchange, (2019). FTSE/JSE Responsible Investment Index. Available at: https://www.jse.co.za/services/market-data/indices/ftse-jseafrica-index-series/responsible-investment-index. Accessed on 07 August 2020.

Khandelwal, M., Sharma, A. \& Jain, V. (2019). Greenwashing: A study on the effects of greenwashing on consumer perception and trust build-up. Research Review International Journal of Multidisciplinary, 4(1), 607-612.

Kurniaty, S., Handayani, S.R. \& Rahayu, S.M. (2018). Stock return and financial performance as moderation variable in influence of good corporate governance towards corporate value. Asian Journal of Accounting Research, 4(1), 18-34. https://doi.org/10.1108/AJAR-07-2018-0021
Kwamega, M., Li, D. \& Abrokwah, E. (2018). Supply chain management practices and agribusiness firms' performance: Mediating role of supply chain integration. South African Journal of Business Management, 49(1), 1-11. https://doi.org/10.4102/sajbm.v49i1.317

Laari, S., Töyli, J., Solakivi, T. \& Ojala, L. (2016). Firm performance and customer-driven green supply chain management. Journal of Cleaner Production, 112, 1960-1970. https://doi.org/10.1016/j.jclepro.2015.06.150

Lannelongue, G., Gonzalez-Benito, J. \& Gonzalez-Benito, O. (2015). Input, output, and environmental management productivity: effects on firm performance. Business Strategy and the Environment, 24(3), 145-158. https://doi.org/10.1002/bse.1806

Laughland, P. \& Bansal, T. (2011). The top ten reasons why businesses aren't more sustainable. Ivey Business Journal, 75(1), 1-14

Leigh, G.R. (2017). Integrated Reporting: The South African Experience. [Online]. Available: https://www.cpajournal.com/ 2017/07/28/integrated-reporting-south-african-experience/. Accessed on 01 April 2018.

Maleka, T., Nyirenda, G. \& Fakoya, M. (2017). The Relationship between Waste Management Expenditure and Waste Reduction Targets on Selected JSE Companies. Sustainability, 9(9), 1-20. https://doi.org/10.3390/su9091528

Manrique, S. \& Martí-Ballester, C.P. (2017). Analyzing the Effect of Corporate Environmental Performance on Corporate Financial Performance in Developed and Developing Countries. Sustainability, 9, 1-30. https://doi.org/10.3390/su9111957

Mans-Kemp, N. (2014). Corporate governance and the financial performance of selected Johannesburg Stock Exchange industries. Doctoral dissertation, Stellenbosch University.

Marashdeh, Z.M.S. (2014). The effect of corporate governance on firm performance in Jordan (Doctoral dissertation, University of Central Lancashire).

Muposhi, A. \& Dhurup, M. (2016). The influence of green atmospherics on store image, store loyalty and green purchase behaviour. In: Proceedings of the 28th Annual Conference of the Southern African Institute of Management Scientists. Management Dynamics : Journal of the Southern African Institute for Management Scientists.

Nugraha, I.P., Rarasati, A.D. \& Adiwijaya, A.J.S. (2019). Analysis of Stakeholder Engagement in the Regional Water Supply System of Jatigede Project: A Study of Actor-Network Theory. In Journal of International Conference Proceedings (Vol. 2, No. 1).

O'Riordan, L. \& Fairbrass, J. (2014). Managing CSR stakeholder engagement: A new conceptual framework. Journal of Business Ethics, 125(1), 121-145. https://doi.org/10.1007/s10551-013-1913-x

Ong, T., Teh, B. \& Ang, Y. (2014). The Impact of Environmental Improvements on the Financial Performance of Leading Companies Listed in Bursa Malaysia. International Journal of Trade, Economics and Finance, 5(5), 386-391. https://doi.org/10.7763/IJTEF.2014.V5.403

Parida, S. \& Wang, Z. (2018). Financial crisis and corporate social responsible mutual fund flows. International Journal of Financial Studies, 6(1), 1-19. https://doi.org/10.3390/ijfs6010008

Pedace, R. (2013). Econometrics for dummies. Hoboken, NJ: Wiley.

Putz, R. (2017). Exploring U-shaped relationships between Corporate Environmental Management Performance and Corporate Financial Performance (A\&C). Masters Dissertation, Radbound University

Ramakrishnan, D. (2008). Financial Performance and Stakeholder Management. [Online]. Available: https://www.researchgate. 
net/publication/228320865_Financial_Performance_and_Sta keholder_Management. Accessed on 17 May 2019.

Riaz, H., Saeed, A., Baloch, M.S. \& Khan, Z.A. (2019). Valuation of Environmental Management Standard ISO 14001: Evidence from an Emerging Market. Journal of Risk and Financial Management, 12(1), 1-14. https://doi.org/10.3390/jrfm12010021

Rokhmawati, A., Gunardi, A. \& Rossi, M. (2017). How Powerful is Your Customers' Reaction to Carbon Performance? Linking Carbon and Firm Financial Performance. International Journal of Energy Economics and Policy, 7(6), 85-95.

Sethibe, T. \& Steyn, R. (2016). Innovation and organisational performance: A critical review of the instruments used to measure organisational performance. The Southern African Journal of Entrepreneurship and Small Business Management, 8(1), 1-12. https://doi.org/10.4102/sajesbm.v8i1.50

Vanalle, R. M., Ganga, G. M. D., Godinho Filho, M. \& Lucato, W. C. (2017). Green supply chain management: An investigation of pressures, practices, and performance within the Brazilian automotive supply chain. Journal of Cleaner Production, 151, 250-259. https://doi.org/10.1016/j.jclepro.2017.03.066

Wang, X. \& Wood, L. C. (2016). The Influence of Supply Chain Sustainability Practices on Suppliers. In Handbook of
Research on Global Supply Chain Management (pp. 531544). https://doi.org/10.4018/978-1-4666-9639-6.ch030

Wijayanto, A., Suhadak, D. M. \& Nuzula, N. F. (2019). The effect of competitive advantage on financial performance and firm value: evidence from Indonesian manufacturing companies. Russian Journal of Agricultural and Socio-Economic Sciences, 1(85), 35-44. https://doi.org/10.18551/rioas.2019-01.04

Yildiz Ç.S. \& Sezen, B. (2019). Effects of green supply chain management practices on sustainability performance. Journal of Manufacturing Technology Management, 30(1), 98-121. https://doi.org/10.1108/JMTM-03-2018-0099

Zaccheaus, S. A., Oluwagbemiga, O. E. \& Olugbenga, O. M. (2014). Effects of corporate social responsibility performance (CSR) on stock prices: Empirical study of listed manufacturing companies in Nigeria. Journal of Business and Management, 16(8), 112-117. https://doi.org/10.9790/487X-1682112117

Zhong, R.Q. (2013). The Bearing of the Cost for Corporate Social Responsibility in the Legal Perspective. Journal of Xiamen University (Arts \& Social Sciences), (1),140-148.

Received on 09-08-2020

Accepted on 03-10-2020

Published on 16-11-2020

DOI: https://doi.org/10.6000/1929-7092.2020.09.42

(C) 2020 Obey Dzomonda; Licensee Lifescience Global.

This is an open access article licensed under the terms of the Creative Commons Attribution Non-Commercial License (http://creativecommons.org/licenses/by-nc/3.0/) which permits unrestricted, non-commercial use, distribution and reproduction in any medium, provided the work is properly cited. 